\title{
Disease in marine aquaculture
}

\author{
C. J. Sindermann \\ Sandy Hook Laboratory, Northeast Fisheries Center, National Marine Fisheries Service, \\ National Oceanic and Atmospheric Administration, U. S. Department of Commerce; \\ Highlands, NJ 07732, USA
}

\begin{abstract}
It has become almost a truism that success in intensive production of animals must be based in part on development of methods for disease diagnosis and control. Excellent progress has been made in $\mathrm{methods}$ of $\mathrm{diagnos}$ is for major pathogens of cultivated fish, crustacean and molluscan species. In many instances these have proved to be facultative pathogens, able to exert severe effects in populations of animals under other stresses (marginal physical or chemical conditions; overcrowding). The concept of stress management as a critical prophylactic measure is not new, but its significance is being demonstrated repeatedly. The particular relationship of water quality and facultative pathogens such as Vibrio, Pseudomonas and Aeromonas species has been especially apparent. Virus dise a s s of marine vertebrates and invertebrates - little known two decades ago - are now recognized to be of significance to aquaculture. Virus infections of oysters, clams, shrimps and crabs have been described, and mortalities have been attributed to them. Several virus diseases of fish have also been recognized as potential or actual problems in culture. In some instances, the pathogens seem to be latent in natural populations, and may be provoked into patency by stresses of artificial environments. One of the most promising approaches to dise ase prophylaxis is through immunization. Fish respond well to various vaccination procedures, and new non-stressing methods have been developed. Vibriosis - probably the most severe disease of ocean-reared salmon - has been controlled to a great extent through use of a polyvalent bacterin, which can be modified as new pathogenic strains are isolated. Prophylactic immunization for other bacterial diseases of cultivated fish has been attempted, especially in Japan, with some success. There is also some evidence that the larger crustaceans may be immunologically responsive, and that at least short-term protection may be afforded to cultured populations. Some progress has been made in marine disease control through $\mathrm{ch}$ e $\mathrm{m} \mathrm{ic} \mathrm{a} 1 \mathrm{tre}$ a $\mathrm{tme} \mathrm{nt}$ in intensive culture systems, principally through application and modification of methods developed for freshwater aquaculture. Major constraints to use of chemicals are restrictions due to public health concerns about food contamination, and the negative effects of some chemicals on biological filters and on algal food production. There is a continuing need, however, for development of specific treatments for acute disease episodes - such as the nitrofurans, developed in Japan, which are effective for some bacterial diseases. The history of aquaculture - freshwater as well as marine - has been characterized by transfers and introductions of species to waters beyond their present ranges. The process continues, and carries with it the possibility of transfers of pathogens to native species and to the recipient culture environments. International groups are attempting to define codes of practice to govern such mass movements, but examples of introductions of real or potential pathogens already exist. The most recent and the most dramatic is the world wide transfer of a virus pathogen of penaeid shrimps. Earlier examples include the introduction of a protozoan pathogen of salmonids to the western hemisphere, and the introduction of a parasitic copepod from the Far East to the west coast of North America and to France. The conclusion is inevitable diseases are substantial deterrents to aquaculture production. Diagnostic and control procedures are and will be important components of emerging aquaculture technology.
\end{abstract}




\section{INTRODUCTION}

Many hazards confront those daring enough to attempt to produce significant quantities of food from marine aquaculture. Constraints and problems can be categorized as economic, legal, or technical. Among those of a technical nature, none has proved more severe, or resistant to resolution, than disease. Entire aquaculture operations have persisted or disappeared based on success or failure in reduction of disease-caused mortality to acceptable levels. Methods for disease diagnosis and control for marine aquaculture have improved during the past decade (Sindermann, 1970a, 1977), although much remains to be accomplished.

This paper has four principal sections: (1) an attempt to examine the reality of disease problems in selected examples of marine aquaculture - Japanese yellowtail and American and European oysters, emphasizing quantitative information where available, in an effort to demonstrate disease effects; (2) an examination of those pathogen groups which are considered to be universal problems in marine aquaculture - the viruses and the vibrios; (3) a proposed program of disease control, emphasizing stress management, prophylactic immunization, chemotherapy, and control of transfers and introductions; and (4) a summarization of some current concepts about the role of disease in cultured marine species.

Emphasis is clearly on the more pragmatic aspects - disease effects and disease control in aquaculture populations. Only a small sample (but I hope a reasonably representative sample) of the expanding world literature on diseases is included, principally as an illustration of the nature and extent of research effort being applied. A conceptual base for marine aquaculture pathology is developing; its status is also reported here.

\section{DISEASE EFFECTS: THE REALITY OF DISEASE IN MARINE AQUACULTURE}

A knowledgeable American aquaculturist once stated publicly (and maybe perceptively) that it was not disease itself that constituted a restraint on the growth of marine aquaculture, but rather it was the fear of disease and the publicity about disease that frightened away potential investors - thus retarding industry growth. This extreme point of view may have some validity, but the documentation of disease effects on growth of aquaculture is improving, and the role of disease is real and not imaginary. Costs of disease outbreaks, and expenses of disease control have been identified (albeit not frequently enough).

To illustrate the nature and extent of disease impacts on aquaculture, examples have been selected from among those species which have been cultured successfully yellowtail (Seriola quinqueradiata) in Japan, and oysters (Crassostrea spp. and Ostrea edulis) in United States and Europe. Other examples might be used, but those selected should provide a representative sample.

\section{Japanese yellowtail culture}

Japanese marine aquaculture is today undoubtedly the most extensive and productive of any country in the world. Yellowtail, sea bream, and eels are the fish species receiving greatest attention. The national literature on diseases of these species is extensive and 
expanding yearly. Greatest production (over 120,000 tons per year) is derived from sea pen rearing of the yellowtail, and a substantial body of literature documents the important role of disease in yellowtail culture.

During the 1976 FAO Technical Conference on Aquaculture held in Kyoto, Fujiya (1976) summarized the status of what is probably the most successful aquaculture in Japan - that of the carangid fish, Seriola quinqueradiata, in sea pens. Production in 1973, as reported at the conference by Kawatsu et al. (1976) had exceeded 80,000 tons - a sixteen-fold increase in the period of one decade. Since those reports were published, yellowtail culture has expanded still further, reaching 122,000 tons in 1978 (Egusa, 1980), and with expansion have come new disease problems. Parasite and disease control is recognized as a significant aspect of yellowtail culture, and an extensive Japanese literature on the biology, diagnostic features, and control of diseases has developed. As might be expected, microbial diseases (particularly bacterial) have emerged as causes of mortality. Disease problems in yellowtail culture were reviewed recently by Egusa (1980), who provided an excellent historical perspective on the sequential emergence of specific pathogens (Table 1).

Table 1. Sequential appearance of microbial diseases of cultured yellowtail (after Egusa, 1980)

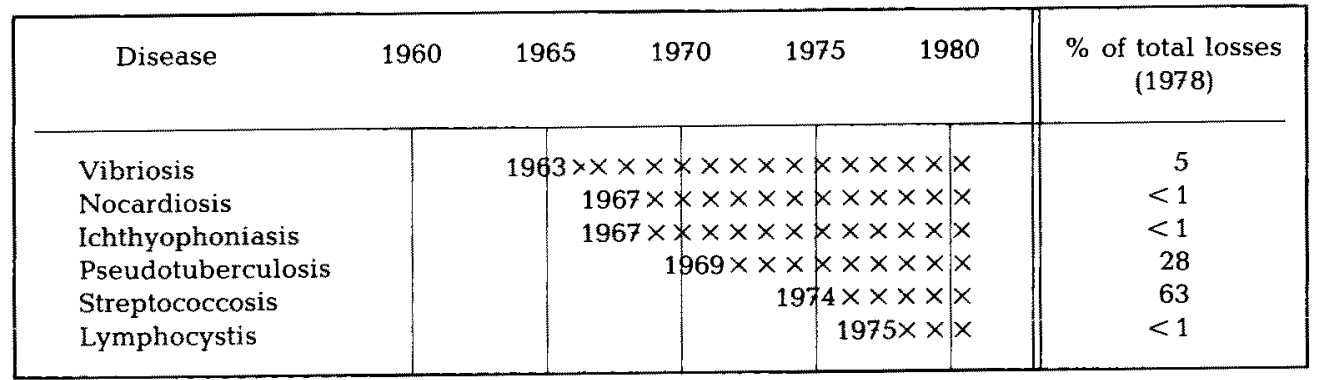

Among the many serious diseases identified during the past two decades by Japanese pathologists are vibriosis, streptococcosis, pseudo-tuberculosis (caused by Pasteurella piscicida), Nocardia infection, lymphocystis, and fungus (Ichthyophonus) infection. Vibriosis has been known since the inception of yellowtail culture (Kubota \& Takakuwa, 1963), primarily as a disease of young fish, and as a dermatitis or enteritis. Chemotherapy has been effective, but losses due to vibriosis in 1978 alone were estimated by Egusa to be 500 million yen (about $5 \%$ of the total disease costs to Japanese yellowtail culture, which were 10,100 million yen). Total value of cultured yellowtail in 1978 was 120,000 million yen. Streptococcosis (caused by an alphahemolytic Streptococcus sp.) was considered by Egusa (1980) to be the most serious disease problem in Japanese yellowtail culture. Damage in 1978 was estimated at 6,400 million yen or $63 \%$ of total losses due to disease. The disease is systemic, with severe enteritis and high mortality. Chemotherapy has been only marginally effective. Another disease, nocardiosis, caused by the gram-positive bacillus Nocardia kampachi, was first reported in 1968 by Kariya et al.(1968). Kusuda (1975) found nocardiosis to be widespread in the various fish farming areas of Japan, where severe mortalities have resulted. Another serious current disease of yellowtail - pseudotuberculosis, caused by $P$. pis- 
cicida - was first reported in 1964 from the coasts of Miyazaki and Kochi Prefectures. It soon spread to the southwestern coast of Japan and now occurs in all Japanese fish farming areas, where it has caused severe mortalities since 1969 (Malsusato, 1975a). The disease is thought to be disseminated by transport of juveniles used to stock floating sea cages. Effects on commercial production of yellowtail were estimated by Matsusato to be a reduction of $1 \%$ or 360 tons in 1972 ; Egusa (1980) estimated damage to yellowtail culture from pseudotuberculosis in 1978 at 2,800 million yen, or $28 \%$ of total disease costs.

Other diseases have been described from cultured yellowtail. Lymphocystis disease, originally named "black spot disease" was described by Matsusato (1975b) as a cause of reduced acceptability of infected fish. Trypanorhynchan cestode larvae (genus Callotetrarhynchus) may be locally abundant in fish from certain growing areas, particularly on the west coast of Shikoku. Poor growth and emaciation result (Nakajima \& Egusa, 1968). A later study disclosed that the early larva of the cestode occurs in anchovies, which are the principal food given to cultured yellowtail (Nakajima \& Egusa, 1968). Control was effected by freezing the food fish, and the disease has ceased to be a serious problem.

The history of diseases in Japanese yellowtail culture can be particularly instructive, in view of the relatively long observation period (more than two decades) and the size and intensity of the commercial production effort. What has emerged is the sequential appearance and spread of new diseases, with related mortalities of varying severity, often with an initial focus in a particular localized coastal area. Scientific attention has led to development of some degree of understanding of the causes, and empirical application of control measures where feasible. The diseases may continue at epizootic levels for a number of years, but then may subside to form part of background mortality especially if control methods are effective to any degree. Almost invariably, though, there are still other diseases, often already present in the population at low enzootic levels or in subacute form, which will emerge and be recognized.

\section{American and European oyster culture}

Oyster populations throughout the world have been characterized by mass mortalities, some of which have been attributed to epizootics of specific pathogens (Sindermann, 1970b, 1979a). Although roughly $70 \%$ of the mass mortalities could not be specifically associated with a cause, disease or otherwise, there have been in recent decades several episodes where deaths were clearly linked to epizootics of viral and protistan pathogens - fungi, and protozoa.

Beginning in the late 1940 's, mortalities due to epizootic diseases occurred in oyster (Crassostrea virginica) populations on the Atlantic and Gulf of Mexico coasts of North America. Initial studies in the Gulf (Mackin et al., 1950; Ray, 1954; Mackin, 1962) identified a fungus pathogen (Dermocystidium marinum [now Perkinsus marinus]) as the causative agent. Direct transmission was demonstrated, and a management scheme based on biological characteristics of the pathogen reduced the effects of the disease on oyster production. (The pathogen is, however, still a significant mortality factor in some growing areas.)

Then, in the late 1950's new and drastic mortalities began in Delaware and Chesapeake Bays, the principal oyster producing areas of the Middle Atlantic coast. 
Intensive studies by federal, state, and university investigators disclosed the presence of two protozoan (haplosporidian) pathogens Haplosporidium nelsoni and Haplosporidium costalis (the former being more important). Mortalities in the early years of the epizootics reached $90 \%$ on some beds, and have continued at a reduced level to the present time. Oyster production declined sharply, especially in Delaware Bay, and has remained depressed in the presence of the pathogen H. nelsoni (Fig. 1). Much has been learned about the pathogen, but its life cycle and method of transmission are still problematic, despite extensive literature and 25 years of study (Wood \& Andrews, 1962; Haskin et al., 1966; Couch et al., 1966; Farley, 1967; Andrews \& Frierman, 1974; Andrews, 1979; Haskin \& Ford, 1979; Ford \& Haskin, 1982; Haskin \& Ford, 1982; and others). The pathogen is intolerant of extended salinities below $15 \mathrm{ppt}$, which has enabled the development of some management methods to reduce mortalities. Also, some evidence for cyclic activity has been found (Fig. 2).

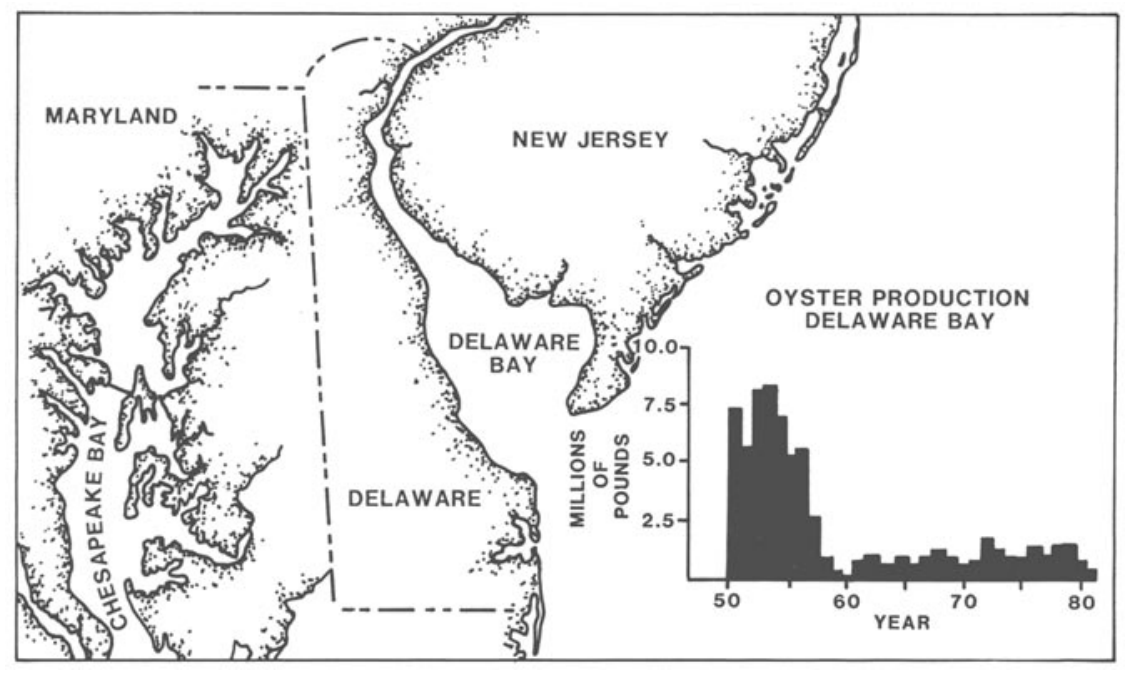

Fig. 1. Oyster production in Delaware Bay (1950-1981)

During the late 1960's and the 1970's, epizootics of similar proportions occurred on the northern coast of France, involving two intensively cultivated species of oysters, the "Portuguese" oyster (Crassostrea angulata) and the European or flat oyster (Ostrea edulis). Mortalities, beginning in the late 1960's, were caused by successive epizootics of quite distinct pathogens.

Abnormal mortalities of Portuguese oysters, $C$. angulata, were first noted on the Atlantic coast of France in summer 1966 (Marteil, 1969; Comps et al., 1976). Diseased oysters had extensive lesions of gills and palps. In the growing areas most affected, as many as $80 \%$ of the oysters were infected, and the overall mortality associated with this "gill disease" was estimated at $40 \%$. Early in the study of the mortalities the etiological agent was thought to be a new protistan pathogen, Thanatostrea polymorpha, but later studies disclosed viral (iridovirus) infections (Comps \& Duthoit, 1976). Gill disease was also observed in Spain, Portugal, and the United Kingdom. 


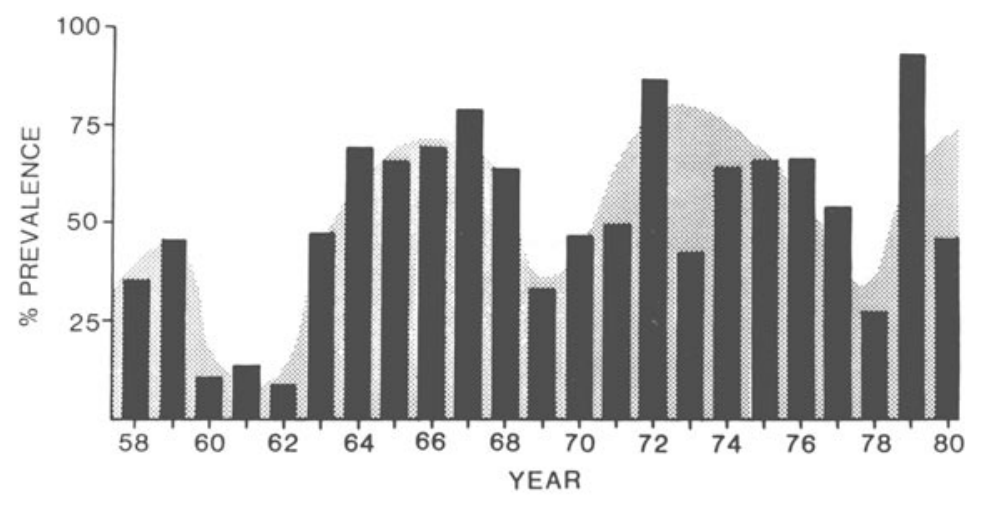

Haplosporidium nelsoni IN DELAWARE BAY

Fig. 2. Variations in prevalence of Haplosporidium nelsoni disease in Delaware Bay oysters (Redrawn from Ford \& Haskin, 1982)

Then, beginning in 1970, new mortalities occurred in C. angulata populations, apparently caused by another iridovirus (Comps et al., 1976). Mortalities continued through 1973, and then subsided. There remains some question as to whether two separate epizootics (1966-1969 and 1970-1973) occurred (and some doubt about the etiology of the 1966-1969 outbreak), but the reality was the almost complete destruction of $C$. angulata populations on the French coast due to epizootic disease. The diminished C. angulata populations were replaced by massive importation and introduction of Pacific oysters, Crassostrea gigas, from Japan and British Columbia (Canada).

During the same period and in the same area, populations of European flat oysters, Ostrea edulis, were also reduced by mortalities resulting from epizootic disease. Beginning in 1968, in estuaries on the French Channel coast, a protistan parasite, Marteilia reftingens, begañ affecting O. cdulis populations (Comps, 1970; Grizel et al, 1974). The pathogen eventually invaded all oyster-growing areas on the Channel and Atlantic coasts of France. Focus of infection was in the digestive gland tubules. The epizootic, with accompanying mortalities, reached a peak in the early 1970's and declined from 1977 on. As the epizootic due to M. refringens in O. edulis waned in the late 1970's and populations began to be rebuilt, another protistan parasite, Bonamia ostreae, was identified as the cause of new mortalities (Comps et al., 1980; Pichot et al,, 1980, 1981). Beginning in summer 1979 on the Brittany coast, the disease has spread to Normandy and Arcachon, and continues at epizootic levels at the present time (1983). Bonamia disease has now been reported from the Netherlands, Denmark and Spain as well.

Here, then, in a period of several decades, some of the major oyster producing areas of the western hemisphere have been seriously impaired by epizootic diseases, and disease has been clearly identified as a factor critical to oyster cultivation.

\section{"UNIVERSAL PATHOGEN GROUPS": VIRUSES AND VIBRIOS}

Each cultivated species of fish and invertebrate can be characterized by an assemblage of pathogens and parasites which assume major or minor roles. The previous section considered such assemblages for yellowtail and oysters, and a comparable list 
could be prepared for eels, salmon, shrimp, or other cultivated species. Examination of such lists would disclose two ubiquitous pathogen problems - virus diseases and vibriosis - which emerge in almost all culture efforts. Because of the almost universal occurrence of these problems, it seems worthwhile to look at each of them in detail.

\section{Virus diseases}

Information about virus diseases of marine fish and shellfish was remarkably scarce before 1970. Examination of earlier literature discloses papers on lymphocystis disease of fish, with demonstrated viral etiology, but little else except for suspected viral involvement in "cauliflower" disease of European eels. With the ready availability of electron microscopy and a variety of fish cell cultures, the recognition and characterization of fish viruses have accelerated remarkably. Additionally, even without established cell cultures for marine molluscs or crustaceans, the recognition and partial characterization of invertebrate viruses have also accelerated.

Some viruses, probably existing in latent form in wild populations, have emerged as pathogens in culture environments, often as a consequence of stressors such as high temperature, overcrowding, inadequate nutrition or poor water quality. Examples of information about latent viral infections being disclosed by stress of abnormal environments include an oyster herpes-like virus disease which caused mortalities when oysters were held at high temperatures (Farley et al., 1972); a shrimp baculovirus which caused mortalities in overcrowded holding tanks (Couch, 1974); a virus disease of clams, disclosed under captive conditions (Brown, 1980); lymphocystis disease of striped bass which increased in prevalence in heated water (Sindermann, 1979b); and a herpes-like virus of turbot, which was lethal at high temperatures (Buchanan et al., 1978).

It should be kept in mind that isolation of the first fish virus (IPN) was reported as recently as 1960, even though diseases such as lymphocystis and carp pox were suspected much earlier to be of viral origin (Weissenberg, 1914; Plehn, 1924; Nigrelli, 1952). As of 1980, 17 fish viruses had been isolated and at least 15 others recognized by electron microscopy (Wolf \& Mann, 1980; Wolf, 1982).

If individual marine species are examined, virus diseases can now be numbered among the major pathogen assemblages. Recent worldwide movements of eels for culture purposes has, almost inadvertently, resulted in discovery of several viral pathogens. Two rhabdoviruses (called EVA and EVEX) were described by Japanese researchers; EVA was isolated from Anguilla rostrata introduced to Japan from Cuba, and EVEX was isolated from Anguilla anguilla imported from France (Sano, 1976; Sano et al., 1977; Nishimura et al., 1981). The introduced viruses were not demonstrated to be pathogenic to Japanese eels, Anguilla japonica. Additionally, severe disease outbreaks caused by a virus similar to IPN virus of salmonids have been reported in eels ( $A$. japonica and $A$. anguilla) from Japan. The virus, antigenically related to IPN of salmonids, and called EVE, has produced extensive annual mortalities in eel culture ponds. It has been transmitted directly and by inoculation in juvenile eels, producing mortalities of 55 to $60 \%$ of experimental fish.

Among crustaceans, the first virus disease was described by Vago (1966). Since then, a bewildering array of viruses has been described (from electron microscopy) in species such as the blue crab by Johnson (1983) and from shrimps (Sano et al., 1981; Lightner et 
al., 1983). Some (but not all) of the described viruses have been associated with disease and mortality, in captivity or in culture. A baculovirus (Baculovirus penaei) was described (Couch, 1974) as a pathogen of penaeid shrimps (Penaeus duorarum and $P$. aztecus) from the Gulf of Mexico, and a counterpart viral pathogen was recently described from cultured Kuruma prawn ( $P$. japonicus) from Japan (Sano et al, 1981). There is some evidence that the Gulf of Mexico virus may cause epizootic mortalities in wild shrimp populations (Couch et al., 1975) and the Japanese report described mortalities of larvae and postlarvae which have occurred since 1971, severe enough to reduce seed production to inefficient levels.

Among marine molluscs, viruses have been associated with disease and mortality of oysters in United States and France by Farley et al. (1972) and Comps \& Duthoit (1976). A more problematic association between virus and haematopoietic neoplasms in clams was made by Oprandy et al. (1981).

With the imminent development of marine invertebrate cell cultures, the coming decade should be one of rapid expansion of knowledge about viruses in marine animals - some of which may be (will be) of importance in aquaculture.

\section{Vibriosis}

The genus Vibrio is abundantly represented in the oceans and estuaries, where its members participate significantly in the processes of degradation which are important to biological cycles. Some members of the genus can be facultatively pathogenic to stressed animals, and it is this characteristic which is important in the aquaculture environment. At least three species (as usually defined) have been associated with epizootics and mortalities of cultivated animals - vertebrate and invertebrate. These species are Vibrio anguillarum, V. parahemolyticus, and $V$. alginolyticus.

Although usually considered marine organisms, Vibrios can be pathogenic for species cultured in freshwater (Muroga \& Egusa, 1970; Muroga et al., 1976; BaudinLaurencin \& Tangtrongpiros, 1980; Horne, 1982). However, these are usually anadromous or catadromous species, and infections may have been acquired in estuarine/coastal waters.

Vibriosis was first described in fish by Bonaveri in 1718 (cited in Hofer, 1904) and was recognized over a decade ago (Sindermann, 1970b; Evelyn, 1971) as a principal problem in marine aquaculture. Subsequent publications have confirmed this observation repeatedly. Many Vibrios are strongly proteolytic and chitinolytic, as well as halophilic, which probably accounts in part for their success as opportunistic pathogens of marine species in culture.

$V$, anguillarum, the most important fish pathogenic vibrio, was identified a halfcentury ago as the cause of a lethal disease ("red disease") of eels in Europe (Bergman, 1909; Nybelin, 1935); that disease continues to be a principal problem in wild as well as captive populations of eels. Since that early identification, $V$. anguillarum has been associated with mortalities of other fishes, and has been recognized as an overriding problem in every marine fish aquaculture attempt.

$V$. anguillarum infections have been of great consequence in saltwater culture of salmonids. At times it seemed as if the continued existence of seawater cultivation of salmon depended on successful solution to the vibriosis problem, and some aspects of 
the problem still exist today, even though remarkable advances have been made in disease control, particularly through immunization.

Sea pen culture of Pacific salmon of several species, but particularly of coho salmon, Oncorhynchus kisutch, began on the west coast of United States in the early 1970's, and mortalities due to vibriosis were noted almost immediately (Harrell, 1978). Initial approaches to control emphasized antibiotic treatment, but oral and other types of immunization developed rapidly. Immunization by injection of juveniles with killed pathogens was effective but labor-intensive. This method has now been replaced by hyperosmotic spray, and bath immunization, augmented when necessary by antibiotic treatment or use of furanace (where permitted) (Egidius \& Andersen, 1979a, 1979b). Oral immunization has also been demonstrated to be effective (Fryer et al., 1978). Polyvalent bacterins have been produced, and vibriosis, while still a problem, is now considered a controllable factor in salmon cultivation in the Pacific Northwest and in European waters.

Control of vibriosis in cage culture of Atlantic salmon, Salmo salar, in the northeastern United States and in northern Europe has profited from advances made in the Pacific. The disease, for example, has been a threat to Norwegian cage culture, particularly in coastal areas where vibriosis epizootics have also occurred in wild populations of saithe, Gadus virens (Egidius \& Andersen, 1975).

$V$. anguillarum has two major biotypes I and II differing antigenically and biochemically - to the point where one author (Schiewe, 1981) has proposed two species, renaming Biotype II as $V$. ordalii. Many highly virulent strains of $V$. anguillarum isolated from epizootics contain a plasmid which enables them to compete successfully for available free iron in fish tissues. This may help to explain, in part, their pathogenicity (Horne, 1982). It should be noted too that $V$. anguillarum strains which are highly pathogenic for one fish species may be non-pathogenic for another species.

Vibrios have also emerged as important pathogens of cultured shrimp. V. parahemolyticus, which has been associated with human gastroenteritis in several countries, was found to be lethal to experimental populations of brown shrimp, P. aztecus, by Vanderzant et al. (1970). Subsequent studies have shown that other vibrios ( $V$. anguillarum, $V$, alginolyticus) can cause epizootics and mortalities of brown shrimp, pink shrimp (P. duorarum) and white shrimp (P. setiferus) (Lewis, 1973; Lightner \& Lewis, 1975). Mortalities attributable to $V$. alginolyticus infection were reported in 1972 and 1973 in a commercial hatchery in the United States (Lightner, 1975). Both white and brown shrimp were affected, and mortalities approached $100 \%$. In this and other reports, the importance of physical or chemical stress in onset of disease was emphasized.

Vibrio spp., as well as members of the genera Beneckea and Pseudomonas with chitinolytic capacities, are also responsible for another significant problem in shrimp culture - shell disease (Cook \& Lofton, 1973). Epizootics and resultant low but persistent mortalities have been reported from an experimental shrimp farm by Lightner (1975), who considered the chitinoclastic bacteria (in this case $V$. anguillarum), to be the primary pathogen.

Vibriosis was and is an important problem in molluscan shellfish hatcheries (Tubiash et al., 1965; Tubiash, 1975; Elston et al., 1982). Epizootics still occur in larval oyster populations (Blogoslawski et al., 1978; Brown, 1973, 1981; Brown \& Losee, 1978; 
Leibovitz, 1978). Vibriosis was also recently implicated in mortalities of abalones, Haliotis rufescens, on the west coast of United States by Elston \& Lockwood (1983).

\section{A DISEASE CONTROL PROGRAM}

Disease control in intensive culture systems is obviously critical - and it is feasible with the appropriate application of measures designed to reduce risks of losses due to this environmental factor. A proposed control program should contain a minimum of four elements (Fig. 3): stress management, prophylactic immunization, chemoprophylaxis/chemotherapy, and control of transfers and introductions. For

\section{CONTROL OF TRANSFERS \\ AND INTRODUCTIONS}

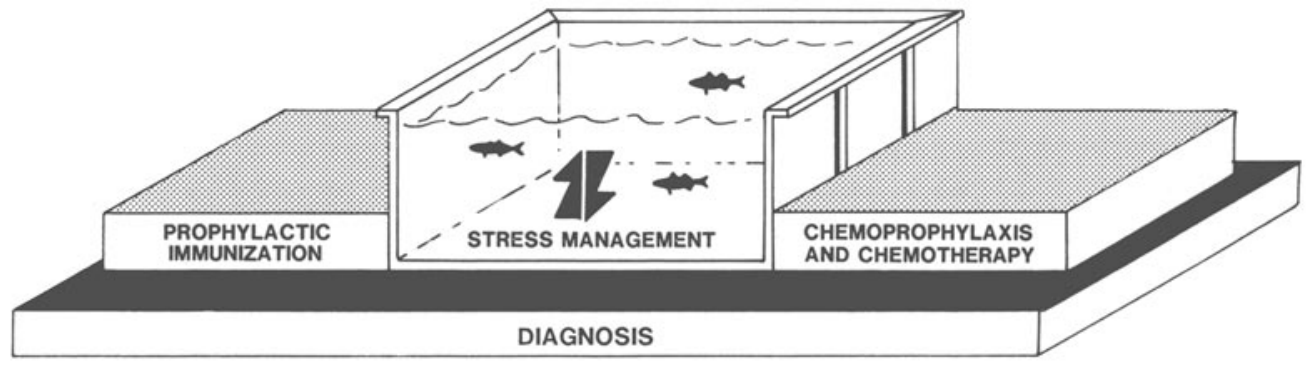

Fig. 3. Principal elements of a disease control program for intensive marine aquaculture

extensive culture systems stress management, prophylactic immunization and control of transfers and introductions remain as key elements, but others may be added, such as environmental or stock manipulation (current diversions, salinity modification, etc.). It might be well to mention at this point that the proposed measures, regardless of the nature of the culturesystem, must be based on the availability of adequate diagnostic services. Identification and biological/ecological characterization of pathogens usually precede or accompany development of effective disease control.

\section{Stress management}

Stress management as a prophylactic method is not a new concept; concern about effects of poor water quality, overcrowding, inadequate diet, abnormal temperatures and salinities have long been features of aquaculture practice. Among the many aspects of stress which are relevant to captive marine populations are these:

(1) chronic marginal physical/chemical conditions, commonly called poor water quality, can be important determinants of mortality; (2) facultative pathogens, especially vibrios and pseudomonads, are particularly effective when individuals are stressed; 
(3) latent infections, introduced with hosts to aquaculture environments, can become patent in stressed populations; and (4) even though concepts of physiological stress were developed for vertebrates, it is becoming apparent that invertebrate stress responses exist and have been described for several species. Some stress management activities are diagrammed in Figure 4.

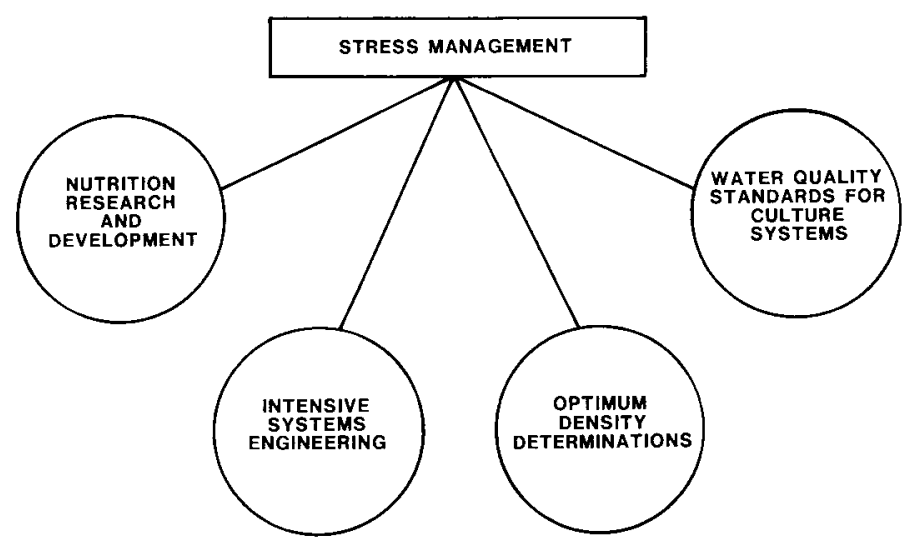

Fig. 4. Principal components of a stress management program for intensive marine aquaculture

Stress is a significant but elusive concept in biology, and, like any concept, it can be misunderstood, misinterpreted, or abused. In its original sense, as developed by Selye (1950, 1955 and 1976), stress represents the consequences of all the mechanisms whereby an organism attempts to maintain equilibrium in the face of environmental change. Selye's original description of stress emphasized physiological responses of the organism in three phases - al arm, resistance, and exhaustion. The alarm phase includes immediate or short-term behavioral, biochemical or physiological responses to non-optimum changes in the environment; the resistance or adaptation phase includes longer-term biochemical/physiological responses which improve likelihood of survival in the non-optimal environment; and the exhaustion phase includes failure of critical biochemical functions leading to physiological and morphological disorders and death.

Perspectives on stress will vary with the background of the observer. To the pathologist many of the responses to stressors can be described as or result in "disease" if disease is defined as "any departure from normal structure or function of the animal". Specific responses to stressors, from the viewpoint of the pathologist, include (in probable descending order of priority): (1) the classical cell and tissue changes such as in $\mathrm{l}$ a m m ation (acute and chronic), degener ation (including edema, necrosis, and metaplasia), r e pair and re ge ner a tion (proliferation, hyperplasia, and scar formation), neoplasia (including consideration of cell origin, stage, and type whether benign or malignant), and genetic derangement (including chromosomal changes, and some skeletal abnormalities); (2) changes in resistance to infection - usually by reduction in immunocompetence; and (3) physiological, biochemical, and behavioral changes. 
An important but often overlooked aspect of stress is that it has two components the non-specific stress responses which collectively make up the so-called "general adaptation syndrome", and the specific or localized stress responses superimposed as a consequence of injury or infection of a particular tissue or organ - direct physiological and/or morphological responses. These, as was pointed out by Selye (1955), may modify the non-specific reactions to the same stressor.

Another important aspect of stress management which has emerged clearly in aquaculture concerns latent infections - their occurrence in wild stocks and their expression as epizootics in captive populations. Latent viral infections have been recognized and described as a consequence of patent disease outbreaks following stress. Included here would be a herpes-like virus infection of oysters (Farley et al., 1972), and a baculovirus disease of shrimp (Couch, 1974, 1978; Couch et al., 1975). Other kinds of latent infections (other than viruses) can also cause disease and mortalities in marine culture. Recently, severe anemia accompanied by extensive systemic lesions were reported in cultured turbot, Scophthalmus maximus, as a consequence of hemogregarine (Haemogregarina sachai) infections (Kirmse, 1980). The hemogregarines are common blood parasites of fish, but are considered benign in wild populations. It may well be that this group, and others with normally low pathogenicity, may assume greater importance under stresses of intensive culture conditions.

The literature on stress in fish is abundant - to the point where two books have been written on the subject (Wedemeyer et al., 1976; Pickering, 1981). The effects of stress in eels has been the subject of a remarkable series of papers by $G$. Peters and her associates (Peters et al., 1980a, b; Peters, 1982). Morphological and physiological indicators were useful in diagnosis of stress in experimental systems.

One of the most important consequences of stress is increased susceptibility to disease; in fact, disease in aquaculture populations is usually an indication of marginal or poor environmental conditions. This is especially true of diseases caused by facultative pathogens such as vibrios, pseudomonads, and aeromonads.

Although most studies of the physiological and morphological consequences of stress have emphasized vertebrates, there are indications that counterpart phenomena may exist in invertebrates as well.

Among Mollusca, several publications have provided evidence for a generalized response syndrome. Jeffries (1972) working with clams, Mercenaria mercenaria, found a shortened life span, mass mortalities, reduction in total amino acid and carbohydrate content, and shell invasion by Polydora in stressed clams. He considered amino acid ratios, particularly the taurine/glycine ratio in gill and mantle tissues, as the best indicators. Ratios above 3 indicate stress, with ratios above 5 an indication of acute stress. High taurine ratios were also observed by Feng et al. (1970) in oysters infected with the trematode Bucephalus. In Jeffries' study, exposure of clams to petroleum resulted in black tar-like concretions in amebocytes and kidney tissues. The concretions collected in the renal sac and plugged the kidney tubules.

Other indices of stress in molluscs have been proposed - particularly reduced "scope for growth" (a measure of the potential for somatic growth and gamete production) (Bayne, 1975; Bayne et al., 1979) and the oxygen/nitrogen ratio (Corner \& Cowry, 1968; Bayne \& Scullard, 1977). Working with mussels, Bayne and associates observed decline in condition and depression of gametogenic activity under stress conditions. 
Other studies by Moore $(1976,1977)$ related degree of cell damage due to destabilization of lysosomal membranes to degrees of stress.

An important aspect of stress management in marine aquaculture is early recognition of abnormality. In bivalve molluscs signs of stress may include mantle recession, pale digestive gland, regression of digestive tubule epithelium, hemocyte infiltration of tissues, edema, lag in gametogenesis, and increased ceroid (brown bodies) - all or most of which constitute a stress syndrome (Fig. 5).

In the larger Crustacea, signs of stress include black gills, abdominal muscle opacity, molt retardation, exoskeletal overgrowth with filamentous bacteria and protozoan epibionts, frequent occurrence of shell disease, disoriented behavior, presence in the tissues of gram positive bacteria, and clotting of the hemolymph (as a response to gram-negative endotoxin) - again constituting a stress syndrome (Fig. 6).

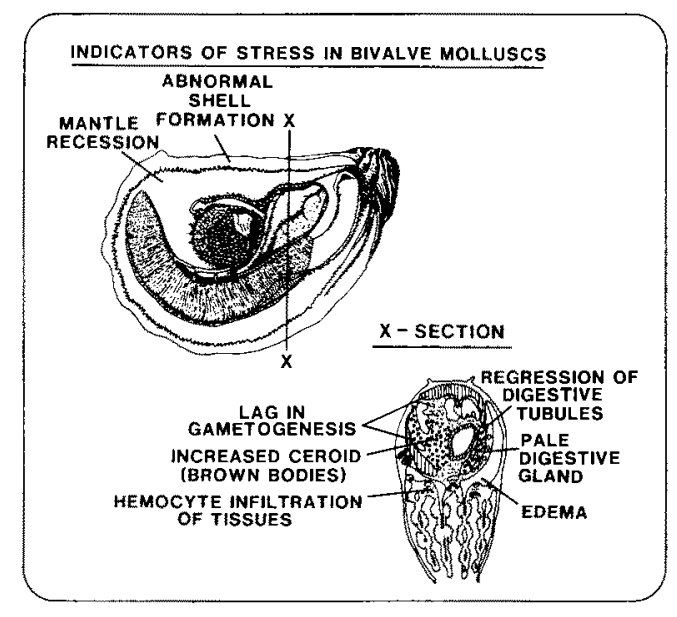

Fig. 5. Some responses to stress in bivalve molluscs

\section{Prophylactic Immunization}

Vaccination (or prophylactic immunization) is and has been a standard practice for protection of humans and other economically important terrestrial vertebrates from disease. Principal types of vaccines, as categorized by Brown (1978) are: (1) Bacterins (inactivated bacterial vaccines); (2) modified live bacterial vaccines; (3) toxoids (for diseases caused by toxins); (4) inactivated viral vaccines; and (5) modified (attenuated) live viral vaccines (which stimulate both humoral and cell mediated immunity).

Each method has utility and deficiencies. Inactivated vaccines do not usually produce strong or long-lasting immunity; overinactivation may destroy the antigen; and inactivation may be incomplete, allowing contact with live virulent pathogens. On the other hand, attenuated microorganisms may mutate to a virulent state (Ellis, 1981, 1982).

Fish vaccine development poses special problems - the most significant of which is temperature dependence. Sensitization and antibody production have been shown to be separate phenomena, with the latter being temperature dependent. Group vaccination to 


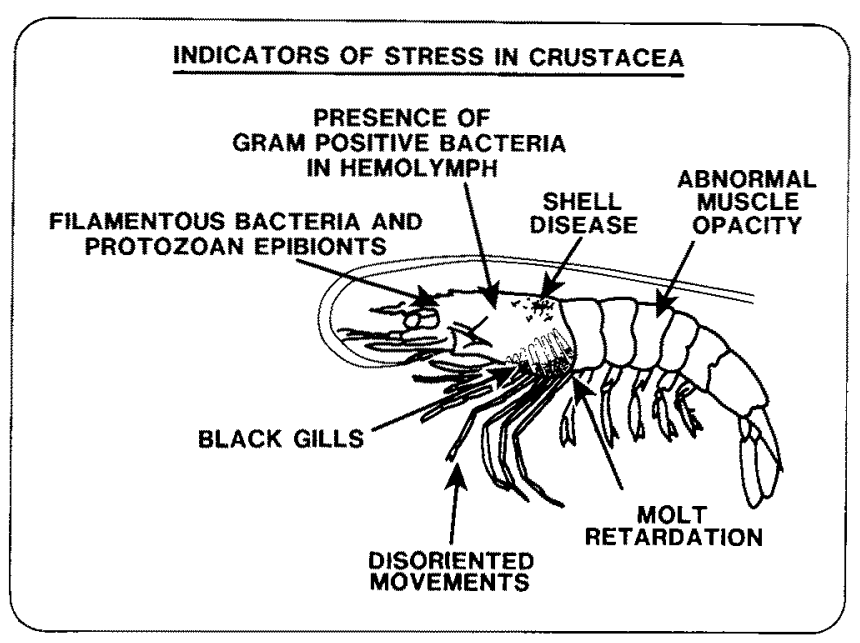

Fig. 6. Some responses to stress in crustaceans

confer "herd immunity" is the goal in fish immunization - not the protection of every single individual as is the case with humans.

Prophylactic immunization received great impetus in marine aquaculture from the necessity of reducing effects of Vibrio disease in cage-reared salmonids. Extensive research conducted on the Pacific coast of United States and elsewhere (Fryer et al,, 1978, Harrell, 1978; Johnson et al., 1982, and others) during the past decade explored various immunization methods. Non-traumatic mass application techniques (such as spray, immersion and hyperosmotic) have been developed and applied, and multivalent bacterins have been available since 1977. Vaccination with Vibrio bacterin has been successful with most salmonid species. Fry as small as one gram can be vaccinated successfully; and resistance persists for more than 400 days if fry are larger than 4 grams at vaccination. The most commonly used (and commercially available) bacterin is bivalent, and confers protection from $V$. anguillarum isolated from United States, Japan, Norway, and Italy (Johnson, 1980). Prophylactic immunization is now used routinely in Atlantic salmon pen culture (Egidius \& Andersen, 1979b).

An emerging phenomenon, both in North America and in Europe, is the appearance of new strains or serotypes of $V$, anguillarum, which must be incorporated into the immunization protocol (Egidius et al., 1981). Bacterins of west coast origin have been augmented with fractions reactive with additional strains of Atlantic Vibrios to control disease in United States east coast and European stocks. The probability of a large number of serotypes complicates bacterin production, and requires constant vigilance to detect new forms of the disease. Some cross-protection is provided by various vaccines, but not enough and not consistently. The outstanding success with Vibrios has led to exploration of prophylactic immunization for control of other diseases of salmonids especially bacterial kidney disease, furunculosis and enteric redmouth disease.

Japanese researchers have developed immunization methods for some of the bacterial diseases of yellowtail (Seriola quinqueradiata) which were discussed earlier in this paper. The efficacy of prophylactic immunization against Pasteurella piscicida, the 
causative agent of pseudotuberculosis has been demonstrated recently (Fukuda \& Kusuda, 1981). Protection was achieved in experimental populations by oral, spray, and immersion methods of immunization of juveniles. Similar studies indicated effectiveness of immunization against streptococcal disease, which is probably the most pressing current disease problem in yellowtail culture (lida et al., 1982).

One feature of vaccination which has emerged is that it is not a panacea, since its protective effects may be reduced drastically by stress. Another limitation of a vaccination program for cultured fish was pointed out by Munro (1982). Vaccinated fish may carry and shed bacterial pathogens, even if they do not show frank disease. This can provide a persistent disease reservoir for susceptibles. Still another point is that immunization is only one of many mechanisms of internal defense available to the fish. The critical role of the liver in detoxification, as well as the sequestering activities of certain tissue components should all be included. Important components of an immunization program for marine fish culture are diagrammed in Figure 7.

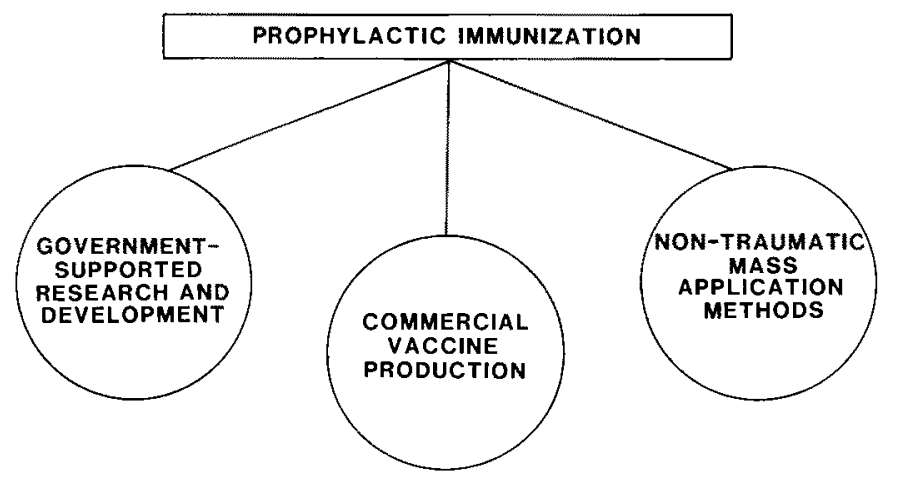

Fig. 7. Important components of an immunization program for marine fish culture

Before leaving the topic of prophylactic immunization, it would be logical to examine the possibilities for enhanced disease resistance in invertebrates which are being produced by aquaculture. The invertebrate responses to infection are markedly different from those of fishes, being less specific and largely cellular (Bang, 1975). Recent work with American lobsters (Paterson \& Stewart, 1974) has demonstrated increased phagocytic activity, with a suggestion that vaccines prepared from avirulent strains of the pathogen Aerococcus viridans produced a limited degree of resistance to the disease (Gaffkaemia) which it causes. Additionally, injections of antibiotic (Vancomycin) plus virulent bacteria provided short-term protection. In other studies, increased bactericidal activity, following injection of bacterial antigen, was found to exist in spiny lobsters (Acton et al., 1969).

Certainly more work needs to be done, especially with the larger Crustacea, on the enhancement of individual resistance to disease. Prophylactic enhancement of nonspecific resistance - possibly by exposure of post larvae to killed or attenuated pathogens - may prove to be the crustacean counterpart of prophylactic immunization in fish. It seems more likely, though, that a more appropriate research approach for invertebrates generally is that of enhanced population resistancebygenetic 
selection. Several examples of the likelihood of success of this approach exist. Development of disease resistance in populations of oysters exposed to epizootic levels of particular pathogens is suggested by recent observations. A high degree of natural selection for disease resistance in oyster populations exposed to the protozoan Haplosporidium nelsoni has been reported recently by Andrews \& Frierman (1974). An unknown pathogen responsible for extensive oyster mortalities (1916-1959) in the Gulf of Saint Lawrence, Canada, has also resulted in selection for disease resistance, in that oysters from other areas die when introduced, whereas native oysters do not die at present. The objective of resistant stocks is a logical one for any genetic modification program with controlled reproduction.

\section{Chemotherapy}

Another important element in the array of marine disease control measures is chemotherapy - useful when other measures fail, but demanding in precision of application, and subject to decreasing effectiveness because of drug resistance. Chemical prophylactic and treatment methods, particularly for salmonid fishes, have been elaborated during the past half century. An extensive technology of disease control necessarily paralleled the development of fish culture in freshwater, and has been applied recently to marine problems. Beginning with the simpler chemical measures (formalin, copper sulfate, malachite green), treatments have progressed through the sulfa drugs to antibiotics and the nitrofurans - a class of chemotherapeutics first developed by the Japanese against bacterial fish diseases. With all this chemistry, we often lose sight of the fact that control of disease should logically concentrate on prophylaxis rather than treatment - and prophylaxis must emphasize adequate water quality and nutrition, as well as reduction of as many stresses on cultured populations as possible. Chemical prophylaxis (and probably chemotherapy) should be considered as "last resort" methods in disease control, as was pointed out by Herman (1970) and Snieszko (1974).

The application of chemicals when a disease outbreak is anticipated (as for example when fish are to be stressed by handling or temperature change) has long been standard practice in freshwater hatcheries. Snieszko (1974) pointed out that such chemoprophy-

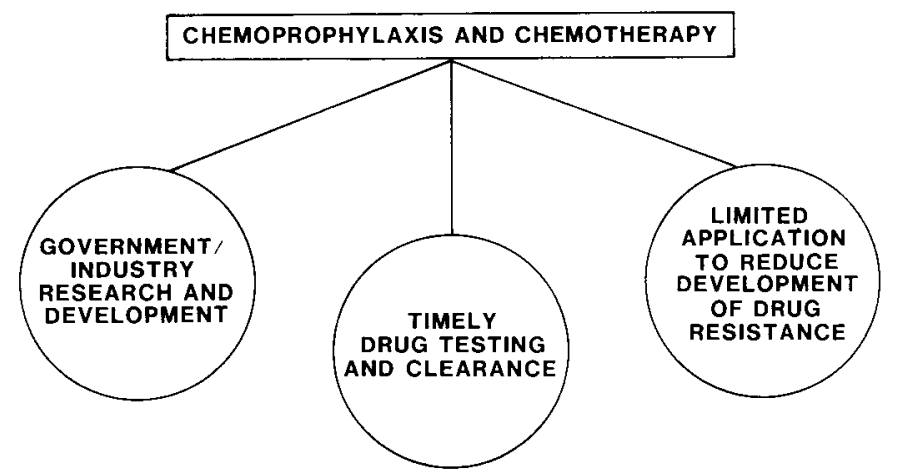

Fig. 8. Important components of a chemoprophylaxis/chemotherapy program for marine aquaculture 
laxis may be useful for salmonids, or in pretreatment of incubating fish eggs. However, as he also pointed out, the danger of chemoprophylaxis (and chemotherapy too) is in developing strains of pathogens resistant to the drug being used. There is already some indication that this is occurring in marine fish culture. Outbreaks of vibriosis caused by drug resistant strains of Vibrio anguillarum have been reported in cultured ayu Plecoglossus altivelis since 1973 from several districts of Japan (Aoki et al., 1974; Kitao et al., 1983). As a consequence, chemotherapeutics have been largely supplanted there by vaccination in vibriosis control.

The technology of prophylaxis and treatment of diseases in marine aquaculture is extremely incomplete. Some of the remedies developed for control of freshwater fish diseases can be adapted for use with marine fish, but the whole field of marine disease control through chemotherapy requires extensive experimentation. Critical components of a chemotherapy program are diagrammed in Figure 8.

Chemicals added to culture systems for disease control may perform two important positive functions: (1) they may reduce or eliminate pathogens, and (2) they may reduce or control populations of heterotrophic microorganisms which may act as facultative pathogens of animals under stress. Such chemicals may, on the other hand, cause problems in culture systems: (1) they may have negative effects on biological filters in controlled recirculated systems - particularly on nitrifying bacteria; $(2)$ they may have negative effects on algal food, or on algae present in fish larval rearing tanks; and (3) they may leave undesirable or harmful residues in cultured animals.

One very important general point which must be kept clearly in mind when considering chemical methods of disease control is the restriction on use of chemicals to treat animals being raised for food. Such restrictions vary from country to country, of course. At present, for example, only salt, acetic acid and sulfamerazine are approved by the United States Food and Drug Administration for use on all food fish, while oxytetracycline is restricted to use with trout, salmon, and catfish. This means that such common and useful substances as formalin, furanace, copper sulfate, acriflavin, and potassium permanganate may not be used legally at present in the United States in treatment of species destined for human consumption.

It should also be pointed out that some chemicals (such as malachite green) may be carcinogenic, or may cause other damage to humans who handle the compounds. Some potentially harmful chemicals may actually be used, even though they are not cleared, and use of such chemicals may leave persistent residues in the harvested product destined for human consumption. Other chemicals may affect food chain organisms in the natural environment; their widespread use should be discouraged.

With all its limitations, as outlined above, chemoprophylaxis and chemotherapy still occupy a significant niche for response to crises or otherwise intractable problems, and profit-oriented aquaculture producers are most comfortable when "remedies" are at hand. As an example, one recent and somewhat unique application of chemotherapy (using ozone and Bactipal) was reported by French researchers. In a search for methods to reduce effects of the protistan parasite Bonamia ostreae on flat oysters, Ostrea edulis, infected oysters and effluents of holding basins were treated. In preliminary experiments, Bactipal was lethal to $B$. ostreae at one part per thousand for $30 \mathrm{~min}$, and ozone was effective at $3.5 \mathrm{mg} / 1$ for $60 \mathrm{~min}$ (Grizel, 1983, unpubl. report). 


\section{Control of transfers and introductions}

Transfers and introductions of species, from one hydrographic regime to another, or from one ocean to another, have characterized the development of marine aquaculture. Such activities are accelerating; and the risk of introduced disease is always present. Some attention is being given to that risk, but adequately documented examples of disease introductions are rare so far for marine species. Specific illustrations include introduction of a parasitic copepod (Mytilicola orientalis) from Japan to the west coast of United States with introduced Pacific oysters (Crassostrea gigas), and the introduction of a virus disease to Hawaii (and possibly elsewhere) with introductions of penaeid shrimps from Central and South America (Lightner et al., 1983). The shrimp virus, called Infectious Hypodermal and Hematopoietic Necrosis Virus (IHHNV) is highly lethal to Penaeus stylirostris and infective to $P$. vannamei and $P$. monodon. It has apparently been widely distributed throughout the world with uncontrolled introductions for aquaculture purposes of infected $P$. stylirostris or $P$. vannamei from the west coast of Central and South America. Its potential infectivity to other commercial penaeid species is as yet undetermined, but an obvious hazard exists. It may well prove to be our best example to date of widespread dissemination of a pathogen with introduced aquaculture species.

Transfers and introductions of non-native species are increasing, and some (such as movement of oyster seed from Japan to the United States Pacific coast and to France) are now considered part of current commercial practice. A parasitic copepod, $M$. orientalis, was introduced to the United States with the early Japanese imports; it proved infective to native west coast oysters Ostrea lurida, and may have contributed to decline of that species. More recently, $M$. orientalis was observed in high prevalences in mussels, Mytilus edulis, from the principal producing areas on the northern French coast (Grizel, 1983; unpubl. report). The parasite was probably introduced with massive imports of Pacific oysters, Crassostrea gigas, from Japan and the west coast of North America.

Usually, though, it is difficult to make direct associations of introduced species and the occurrence of a new pathogen in native populations of the recipient country. Suspected but unproved disease introductions include a viral gill disease of oysters (Crassostrea angulata) in France (Comps et al., 1980) and a protozoan disease of flat oysters (Ostrea edulis) also in France (and more recently in other European countries) (Pichot et al., 1981). In the recent French oyster epizootics, pathogens were identified (an iridovirus responsible for gill disease of Portuguese oysters, C. angulata, and a haplosporidan, Bonamia ostreae, responsible for mortalities of $O$. edulis), which have counterparts in oysters from elsewhere in the world, and may have been introduced recently with massive importations of Pacific oysters (C. gigas). There is, however, no real evidence to support this speculation.

Among the fishes, salmonids have been moved from river to river, country to country, and ocean to ocean, more than any other group (with the possible exception of the carps and tilapias). Such movements have resulted in the introduction of one serious disease - whirling disease caused by the myxosporidian Myxosoma cerebralis - into United States from Europe. At present, attention is focused on a number of highly pathogenic viruses found in salmonids, and on methods to prevent their introduction into waters where they are now absent. Infectious Hematopoietic Necrosis Virus (IHNV) for example, is found in United States but not in Europe, whereas Viral Hemorrhagic Septicemia Virus (VHSV) is found in Europe but not in United States. Inspection and 
certification systems are now in effect in a number of countries to reduce risks of dissemination of these freshwater viral pathogens, but counterpart systems for marine species have not been developed in most countries. Important components of a program to control introductions are diagrammed in Figure 9.

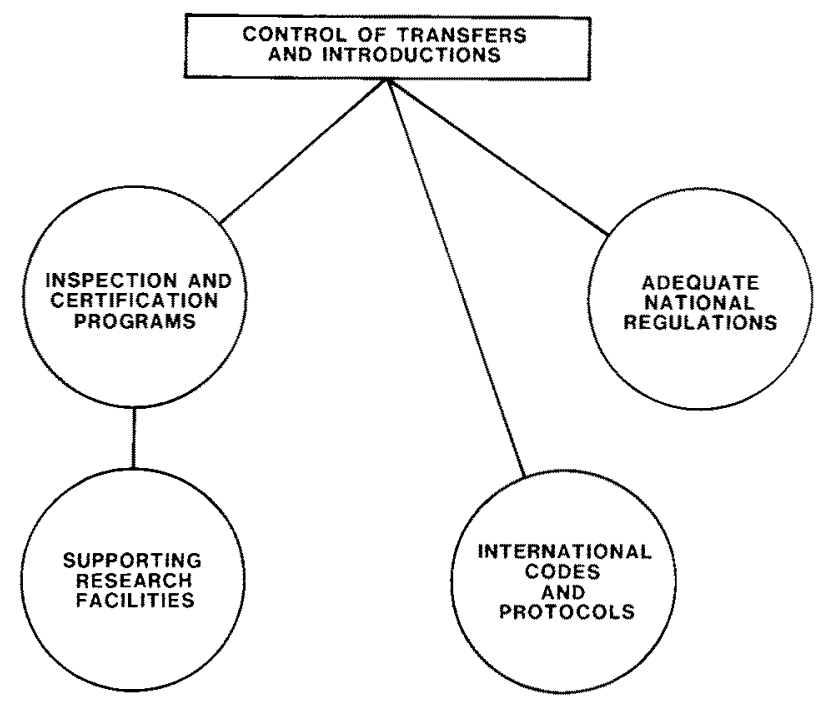

Fig. 9. Important components of a program to reduce risks associated with introductions of nonindigenous species

Recent expansion of ocean ranching and sea cage culture of salmonids has accelerated transfers of fish from country to country. Pacific salmon have been introduced into European waters for cage culture and plans exist for ocean ranching of Pacific species in some European countries (France in particular). Pilot-scale ocean ranching of two Pacific species is already underway on the east coast of United States, based on eggs derived from Alaskan and Japanese stocks. The likelihood of introduction of viral diseases, some of which may be transmitted vertically from parent to offspring, seems high.

There is a general recognition among intergovernmental groups in the western hemisphere (ICES, EIFAC, FAO) of the need for adequate inspection, certification and control programs to reduce risks associated with introductions of species. This recognition has led to a proposal by ICES for an international "Code of Practice", which is reproduced here because of its limited availability in the published literature.

Revised code of practice to reduce the risks of adverse effects arising from introduction of marine species

At its Statutory Meeting in 1973, the International Council for the Exploration of the Sea adopted a "Code of Practice to Reduce the Risks of Adverse Effects Arising from Introduction of Non-indigenous Marine Species". At its Statutory Meeting in 1979 the Council adopted a revised code, as follows:

(1) Recommended procedure for all species prior to reaching a decision regarding new 
introductions (this does not apply to introductions or transfers which are part of current commercial practice).

(a) Member countries contemplating any new introduction should be requested to present to the Council at an early stage information on the species, stage in the life cycle, area of origin, proposed place of introduction and objectives, with such information on its habitat, epifauna, associated organisms, etc., as is available. The Council should then consider the possible outcome of the introduction, and offer advice on the acceptability of the choice.

(b) Appropriate authorities of the importing country should examine each "candidate for admission" in its natural environment, to assess the justification for the introduction, its relationship with other members of the ecosystem and the role played by parasites and diseases.

(c) The probable effects of an introduction into in the new area should be assessed carefully, including examination of the effects of any previous introductions of this or similar species in other areas.

(d) Results of (b) and (c) should be communicated to the Council for evaluation and comment.

(2) If the decision is taken to proceed with the introduction, the following action is recommended:

(a) A brood stock should be established in an approved quarantine situation. The first generation progeny of the introduced species can be transplanted to the natural environment if no diseases or parasites become evident, but not the original import. The quarantine period will be used to provide opportunity for observation for disease and parasites. In the case of fish, brood stock should be developed from stocks imported as eggs or juveniles, to allow sufficient time for observation in quarantine.

(b) All effluents from hatcheries or establishments used for quarantine purposes should be sterilized in an approved manner (which should include the killing of all living organisms present in the effluents).

(c) A continuing study should be made of the introduced species in its new environment, and progress reports submitted to the International Council for the Exploration of the Sea.

(3) Regulatory agencies of all member countries are encouraged to use the strongest possible measures to prevent unauthorized or unapproved introductions,

(4) Recommended procedure for introductions or transfers which are part of current commercial practice.

(a) Periodic inspection (including microscopic examination) by the receiving country of material prior to mass transplantation to confirm freedom from introducible pests and diseases. If inspection reveals any undesirable development, importation must be immediately discontinued. Findings and remedial actions should be reported to the International Council for the Exploration of the Sea.

(b) Inspection and control of each consignment on arrival.

(c) Quarantining or disinfection where appropriate.

Note: A marine species is defined as any aquatic species that does not spend its entire life cycle in freshwater. 
(d) Establishment of brood stock certified free of specified pathogens.

It is appreciated that countries will have different attitudes to the selection of the place of inspection and control of the consignment, either in the country of origin or in the country of receipt.

A schematic plan for introductions, following the Code of Practice, is presented as Figure 10 .

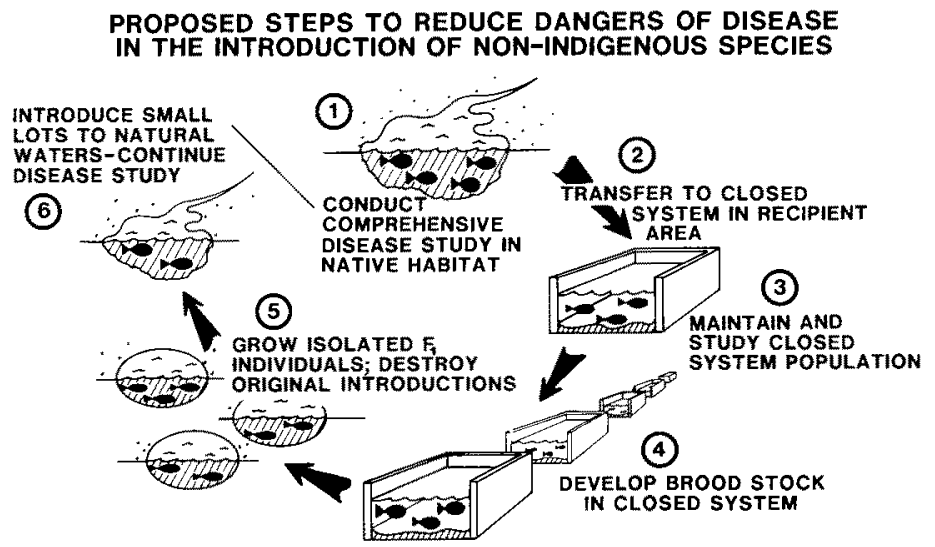

Fig. 10. Steps in introduction of a new species, following the ICES Code of Practice

\section{Environmental or stock manipulation}

Extensive culture systems, in which animals are released into the natural environment for growth to market size, are less amenable to control measures than are intensive systems. Some of the elements already discussed are still applicable to extensive systems. Stress management may consist of controlled density planting of oysters or locating growout areas away from known sources of industrial pollution; prophylactic immunization of fish in ocean ranching is feasible; and control of introductions of nonindigenous species to open waters is a critical element in extensive culture. In addition, environmental or stock manipulation may emerge as the most important disease control element in extensive aquaculture $\mathrm{s}$ y s te $\mathrm{m}$ s. Several examples now exist that demonstrate this. Stock management and planting of oysters in the presence of pathogens is a good case in point. In the case of the fungus pathogen Perkinsus marinus, low density planting of oysters reduces risk of disease transmission; in the case of the haplosporidian pathogen Haplosporidium nelsoni, planting in waters with salinities below $15 \mathrm{ppt}$ is critical to survival; in the case of the French oyster pathogen Marteilia refringens, infections occur in July and August, so seed oysters are not planted during this period. These pragmatic management approaches, utilizing available physiological and ecological information about the pathogen and the host, can insure maintenance of production even in the presence of serious pathogens. 


\section{CONCLUSIONS: EMERGING CONCEPTS IN AQUACULTURE PATHOLOGY}

Any examination of the literature in a rapidly developing speciality of science should result in identification of emerging concepts or generalizations. Such emergence should not be forced, of course, but the role of pathology in marine aquaculture has progressed sufficiently to enable some tentative syntheses. Parallels with findings from other populations - freshwater and terrestrial - are obvious and repeated, but some features unique to the marine environment have appeared:

(1) Prominent in any consideration of marine aquaculture diseases is the overriding presence of Vibrio infections which are facultatively associated with stress, and which are severe problems in the culture of most species, vertebrate and invertebrate.

(2) Closely associated with recognition of vibriosis as a principal problem is the identification of other bacterial diseases of cultivated animals, such as Aerococcus viridans infections in lobsters, and pseudotuberculosis in yellowtail culture, caused by Pasteurella piscicida. Some, such as $A$. viridans can be classified as primary pathogens, while others are facultative, but no sharp division exists.

(3) Facultative pathogens, particularly but not exclusively of the Vibrio, Pseudomonas, Aeromonas group, may under the stresses of low dissolved oxygen, high temperatures, dietary imbalances or high population densities, occur in epizootic proportions in cultivated populations of fish and shellfish. Mortalities caused by nonoptimum environment are thus attributed to disease. The species composition of microorganisms in the vicinity of aquaculture facilities may shift drastically, due to eutrophication or shedding of pathogens from infected fish. Disease outbreaks are clearly aspects of ecosystem dynamics.

(4) As might be expected, based on experiences with freshwater fish culture, the rapid emergence of viral diseases of marine species has followed closely the partial control of principal bacterial pathogens. Previously unexplained disease conditions and mortalities in fish and shellfish populations have been associated with the presence of viruses (Farley et al., 1972; Couch, 1974; Stephens et al., 1980; Lightner et al., 1983), and there is every reason to expect further elucidation of the role of viruses in marine populations.

(5) Disease control in fish selected for marine aquaculture may depend to a large extent on augmentation of the internaldefensemechanisms of the animal, principally by vaccination. The immunological responses of fish generally parallel those of terrestrial vertebrates, including phagocytosis and the elaboration of specific immunoglobulin antibodies. This fact has been used in prophylactic immunization of several species of freshwater fishes, and more recently in successful attempts to immunize saltwater-held salmon against vibrio and other bacterial infections (Fryer et al., 1976; Cisar \& Fryer, 1969). It may be that early prophylactic immunization using a combination of vaccine application methods - plus antibiotics added to diets when disease signs appear - may be methods of choice with microbial diseases of fish.

(6) Latent infections are important in maintaining disease (and some level of disease resistance) in natural populations of fish. They provide a continuing source of infectious material, and may become patent and cause epizootics as a consequence of environmental stress, such as that frequently found in aquaculture systems.

(7) For cultured anadromous or catadromous species such as salmon or eels, the distinction between "freshwater" and "marine" diseases becomes blurred. Some dis- 
eases acquired in freshwater may exert effects during saltwater existence or vice versa. Also some freshwater diseases may be transmitted in saltwater. An emerging phenomenon in sea pen culture of salmon is the appearance of some of the well-known freshwater diseases, such as furunculosis (caused by Aeromonas salmonicida), bacterial kidney disease (caused by Renibacterium salmoninarum), and Viral Hemorrhagic Septicemia (VHS), which have been and continue to be serious hatchery problems, as causes of mortality in seawater as well (Frantsi et al., 1977; Paterson et al., 1981; Castric \& deKinkelin, 1980). These diseases may be carried in a latent state from fresh- to saltwater, but furunculosis and VHS have been transmitted from fish to fish in seawater (Scott, 1968; Novotny, 1978; Castric \& deKinkelin, 1980). Novotny, for example, cited instances of mortalities in sea cages of chinook salmon (Oncorhynchus tshawytscha) of up to $80 \%$ in five months, caused by simultaneous epizootics of furunculosis and vibriosis.

(8) Transfer and introductions of species for aquaculture purposes can increase disease problems in cultivated populations. Susceptible animals may be introduced into areas in which particular diseases are enzootic or epizootic, or new diseases may be introduced when transfers from other geographic areas are made.

(9) Extensive marine aquaculture facilities may serve as epicenters for the dissemination of, or may act as reservoirs for, important pathogens, some of which may affect wild populations.

(10) Disease outbreaks in extensive culture have clear seasonal characteristics, and may also occur in longer-term cycles.

Disease has already proved to be, and will undoubtedly continue to be, a major problem in marine aquaculture. Technological progress in disease diagnosis and control has been rapid, so that our successes now outnumber our failures. The process is never ending, though, as new disease entities and new crises appear to challenge aquaculture production.

\section{LITERATURE CITED}

Aoki, T., Egusa, S. \& Arai, T., 1974. Detection of R factor in naturally occurring Vibrio anguillarum strains. - Antimicrob. Agents and Chemother. 6, 534-538.

Acton, R. T., Weinheimer, P. W. \& Evans, E. E., 1969. A bactericidal system in the American lobster, Homarus americanus, - J. Invertebr. Pathol, 13, 463-464.

Andrews, J. D., 1979. Oyster diseases in Chesapeake Bay. - Mar. Fish. Rev. 41 (1-2), 45-53.

Andrews, J. D. \& Frierman, M., 1974. Epizootiology of Minchinia nelsoni in susceptible wild oysters in Virginia, 1959 to 1971. - J. Invertebr. Pathol. 24, 127-140.

Bang, F., 1975. Comparisons of immune mechanisms in vertebrates and invertebrates. In: Invertebrate immunity. Ed. by K. Maramorosch \& R. E. Shope. Acad. Press, New York, 355-357.

Baudin-Laurencin, F. \& Tangtrongpiros, J., 1980. Some results of vaccination against vibriosis in Brittany. In: Fish diseases. Ed. by W. Ahne. Springer, Berlin, 60-68.

Bayne, B. L., 1975. Aspects of physiological condition in Mytilus edulis L., with special reference to the effects of oxygen tension and salinity. In: Proceedings of the 9th European marine biological symposium. Ed. by H. Barnes, Univ, Press, Aberdeen, 213-238.

Bayne, B. L. \& Scullard, C., 1977. Rates of nitrogen excretion by species of Mytilus (Bivalvia: Mollusca). - J. mar. biol. Ass. U. K. 57, 355-369.

Bayne, B. L., Moore, M. N., Widdows, J., Livingstone, D. R. \& Salkeld, P., 1979. Measurement of the response of individuals to environmental stress and pollution: studies with bivalve molluscs. Phil. Trans. R. Soc. (B) 286, 563-581.

Bergman, A., 1909. Die rote Beulenkrankheit des Aals, - Ber. K. bayer. biol. Vers.-Stn 2, $10-54$. 
Blogoslawski, W. J., Stewart, M. E. \& Rhodes, E. W., 1978. Bacterial disinfection in shellfish hatchery disease control. - Proc. a. Meet. Wld Maricult. Soc. 9, 589-602.

Brown, A. L., 1978. Immunity and practical vaccine development. - Mar. Fish. Rev. 40 (3), $2-5$.

Brown, C., 1973. The effects of some selected bacteria on embryos and larvae of the American oyster, Crassostrea virginica. - J. Invertebr. Pathol. 21, 215-223.

Brown, C. \& Losee, E., 1978. Observations on natural and induced epizootics of vibriosis in Crassostrea virginica larvae. - J. Invertebr. Pathol. 31, 41-47.

Brown, C., 1981. A study of two shellfish-pathogenic Vibrio strains isolated from a Long Island hatchery during a recent outbreak of disease. $-J$. Shellfish Res. 1, 83-87.

Brown, R. S., 1980. The value of the multidisciplinary approach to research on marine pollution effects as evidenced in a three year study to determine the etiology and pathogenesis of neoplasia in the soft-shell clam, Mya arenaria. - Rapp. P.-v. Réun. Cons. perm. int. Explor. Mer $179,125-128$.

Buchanan, J. S., Richards, R. H., Sommerville, C. \& Madeley, C. R., 1978. A herpes-type virus from turbot (Scophthalmus maximus L.). - Vet. Rec. 102, 527-528.

Castric, J. \& deKinkelin, P., 1980. Occurrence of viral hemorrhagic septicemia in rainbow trout Salmo gairdneri Richardson reared in sea water. - J. Fish Dis. 3, 21-27.

Cisar, J. O. \& Fryer, J. L., 1969. An epizootic of vibriosis in chinook salmon. - Bull. Wildl. Dis. Ass. 5، 73-76.

Comps, M., 1970. Observations sur les causes d'une mortalité anomale des huîtres plates dans le Bassin de Marennes. - Revue Trav. Inst. Pêch. marit. 34 (3), 317-326.

Comps, M. \& Duthoit, J.-L., 1976. Infection virale associée à la "maladie des branchies" de l'huitre portugaise Crassostrea angulata Link, - C. r. hebd. Séanc. Acad. Sci., Paris (D) 283, 1595 - 1596.

Comps, M., Bonami, J. R., Vago, C. \& Campillo, A., 1976. Une virose de l'huitre portugaise (Crassostrea angulata Lmk). - C. r. hebd. Séanc. Acad. Sci., Paris (D) 282, 1991-1993.

Comps, M., Tige, G. \& Grizel, H., 1980. Etude ultrastructurale d'une Protiste parasite de l'huître Ostrea edulis L. - C. r. hebd. Séanc. Acad. Sci., Paris (D) 290, 383-384.

Cook, D. W. \& Lofton, S. R., 1973. Chitinoclastic bacteria associated with shell disease in Penaeus shrimp and the blue crab Callinectes sapidus. - J. Wildl. Dis. 19, 154-159.

Corner, E. D. S. \& Cowry, C. B., 1968. Biochemical studies on the production of marine zooplankton. - Biol. Rev. 43, 393-426.

Couch, J. A., 1974. Free and occluded virus similar to Baculovirus in the hepatopancreas of pink shrimp. - Nature, Lond. 247, 229-231.

Couch, J. A., 1978. Diseases, parasites, and toxic responses of commercial penaeid shrimps of the Gulf of Mexico and South Atlantic coasts of North America. - Fish. Bull. U. S. 76, 1-44.

Couch, J. A., Farley, C. A. \& Rosenfield, A., 1966. Sporulation of Minchinia nelsoni (Haplosporida, Haplosporidiidae) in the American oyster Crassostrea virginica. - Science, N. Y. 153, $1529-1531$.

Couch, J. A., Summers, M. D. \& Courtney, L., 1975. Environmental significance of Baculovirus infections in estuarine and marine shrimp. - Ann. N. Y. Acad. Sci. 266, 528-536.

Egidius, E. \& Andersen, K., 1975. Report on an epizootic of vibriosis in the young saithe population along the Norwegian coast. - C. M./ICES/E 43, 1-7

Egidius, E. \& Andersen, K., 1979a. The use of Furanace against vibriosis in rainbow trout Salmo gairdneri Richardson in salt water. - J. Fish Dis. 2, 79-80.

Egidius, E. \& Andersen, K., 1979b. Bath immunization - a practical and non-stressing method of vaccinating sea farmed rainbow trout Salmo gairdneri Richardson against vibriosis. - J. Fish Dis. 2, 405-410.

Egidius, E., Andersen, K., Clausen, E. \& Raa, J., 1981. Cold-water vibriosis or "Hitra disease" in Norwegian salmonid farming. - J. Fish Dis. 4, 353-354.

Egusa, S., 1980. Disease problems in Japanese yellowtail, Seriola quinqueradiata, culture: a review. - ICES Special Meeting on Diseases of Commercially Important Marine Fish and Shellfish. 9, $1-20$.

Ellis, A. E., 1981. Stress and the modulation of defense mechanisms in fish. In: Stress and fish. Ed. by A. Pickering. Acad. Press, London, 147-170.

Ellis, A. E., 1982. Differences between the immune mechanisms of fish and higher vertebrates. In: Microbial diseases of fish. Ed. by R. J. Roberts. Acad. Press, London, 1-29. 
Elston, R. \& Lockwood, G. S., 1983. Pathogenesis of vibriosis in cultured juvenile red abalone, Haliotis rufescens Swainson. - J. Fish Dis. 6, 111-128.

Elston, R., Elliott, E. \& Colwell, R. R., 1982. Conchiolin infection and surface coating Vibrio; shell fragility, growth depression and mortalities in cultured oysters and clams, Crassostrea virginica, Ostrea edulis and Mercenaria mercenaria. - J. Fish Dis. 5, 254-284.

Evelyn, T. P. T., 1971. First records of vibriosis in Pacific salmon cultured in Canada and taxonomic status of the responsible bacterium, Vibrio anguillanm. - J. Fish. Res. Bd Can. 28, 517-525.

Farley, C. A., 1967. A proposed life cycle of Minchinia nelsoni (Haplosporida, Haplosporidiidae) in the American oyster Crassostrea virginica. - J. Protozool. 14, 616-625.

Farley, C. A., Banfield, W. G., Kasnic, G. K. \& Foster, W. S., 1972. Oyster herpes-type virus. Science, N. Y. 178, 759-760.

Feng, S. Y., Khairallah, E. A. \& Canzonier, W. J., 1970. Hemolymph free amino acids and related nitrogenous compounds of Crassostrea virginica infected with Bucephalus sp. and Minchinia nelsoni. - Comp. Biochem. Physiol. 34, 547-556.

Ford, S. E. \& Haskin, H. H., 1982. History and epizootiology of Haplosporidium nelsoni (MSX), an oyster pathogen in Delaware Bay, 1957-1980. - J. Invertebr. Pathol. 40, 118-141.

Frantsi, C., Ritter, J. A. \& Felson, P., 1977. Effect of corynebacterial kidney disease on ocean survival and return of Atlantic salmon (Salmo salar). - C. M./ICES/M 29.

Fryer, J. L., Rohovec, J. S., Tebbit, G. L., McMichael, J. S. \& Pilcher, K. S., 1976. Vaccination for control of infectious diseases in Pacific salmon. - Fish Pathol. 10, 155-164.

Fryer, J. L., Rohovec, J. S. \& Garrison, R. L., 1978. Immunization of salmonids for control of vibriosis. - Mar. Fish. Rev. 40 (3), 20-23.

Fujiya, M., 1976. Coastal culture of yellowtail (Seriola quinqueradiata) and red seabream (Sparus major) in Japan. - FAO tech. Conf. Aquacult. Doc. FIR/AQ/Conf/76/E: 54, 1-10.

Fukuda, Y. \& Kusuda, R., 1981. Acquired antibody against pseudotuberculosis in yellowtail. - Fish Pathol. 15, 263-269.

Grizel, H., Comps, M., Bonami, J. R, Cousserans, F, Duthoit, J.-L. \& Le Pennec, M. A., 1974. Recherche sur l'agent de la maladie de la glande digestive de Ostrea edulis Linne. - Sci. Pêche $240,7-29$.

Harrell, L. W., 1978. Vibriosis and current salmon vaccination procedures in Puget Sound, Washington. - Mar. Fish. Rev. 40 (3), 24-25.

Haskin, H. H. \& Ford, S. E., 1979. Development of resistance to Minchinia nelsoni (MSX) mortality in laboratory-reared and native oyster stocks in Delaware Bay, - Mar. Fish. Rev. 41 (1-2), 54-63.

Haskin, H. H. \& Ford, S. E., 1982. Haplosporidium nelsoni (MSX) on Delaware Bay seed oyster beds: a host-parasite relationship along a salinity gradient. - J. Invertebr. Pathol, 40, 388-405.

Haskin, H. H., Stauber, L. A. \& Mackin, J. A., 1966. Minchinia nelsoni n. sp. (Haplosporida, Haplosporidiidae): Causative agent of the Delaware Bay oyster epizootic - Science, N. Y. 153, 1414-1416.

Herman, R. L., 1970. Prevention and control of fish diseases in hatcheries. pp. 3-15. In: A symposium on diseases of fishes and shellfishes. Ed. by S. F. Snieszko. Am. Fish. Soc., Washington, DC, 526 pp. (Spec. Publ. Am. Fish. Soc. 5.)

Hofer, B., 1904. Handbuch der Fischkrankheiten. Verl. Allgemeine Fischerei Zeitung, München, $359 \mathrm{pp}$.

Horne, M. T., 1982. The pathogenicity of Vibrio anguillarum (Bergman). In: Microbial diseases of fish. Ed. by R. J. Roberts. Acad. Press, London, 171-187.

lida, T., Wakabayashi, H. \& Egusa, S., 1982. Vaccination for control of streptococcal disease in cultured yellowtail. - Fish Pathol. 16, 201-206.

Jeffries, H. P., 1982. A stress syndrome in the hard clam, Mercenaria mercenaria. - J. Invertebr. Pathol. 20, 242-251.

Johnson, K. A., 1980. Development of effective Vibrio vaccination program for salmonid culture.Fish Pathol. 14, 181.

Johnson, K. A., Flynn, J. K. \& Amend, D. F., 1982. Onset of immunity in salmonid fry vaccinated by direct immersion in Vibrio anguillarum and Yersinia ruckeri bacterins. - J. Fish Dis. 5, $197-205$.

Johnson, P. T., 1983. Diseases caused by viruses, rickettsiae, bacteria, and fungi. In: The biology of Crustacea. Ed. by D. E. Bliss. Acad. Press, New York, 6, 1-78. 
Kariya, T., Kubota, S., Nakamura, Y. \& Kira, K., 1968. Nocardial infection in cultured yellowtail (Seriola quinqueradiata and S. purpurascens). I. Bacteriological study. - Fish Pathol, 3, 16-23.

Kawatsu, H., Honma, A. \& Kawaguchi, K., 1976. Epidemic fish diseases and their control in Japan.FAO tech. Conf. Aquacult. Doc. FIR/AQ/76/E:39, 1-7.

Kirmse, P., 1980. Observations on the pathogenicity of Haemogregarina sachai Kirmse, 1978 in farmed turbot, Scophthalmus maximus (L.), - J. Fish Dis. 3, 101-114.

Kitao, T., Aoki, T., Fukudome, M., Kawano, K., Wada, Y. \& Mizuno, Y., 1983. Serotyping of Vibrio anguillarum isolated from diseased freshwater fish in Japan. - J. Fish Dis. 6, 175-181.

Kubota, S. \& Takakuwa, M., 1963. Studies on the diseases of marine-culture fishes. I. General description and preliminary discussion of fish diseases at Mie Prefecture. - J. Fac. Fish pref. Univ. Mie-Tsu 6, 107-124.

Kusuda, R, 1975. Nocardial infection in cultured yellowtails. In: Proceedings of the 3rd US-Japan meeting on aquaculture. Fish. Ag. Jap. Govt, Jap. Sea reg. Fish. Res. Lab., 63-66.

Lewis, D. H., 1973. Response of brown shrimp to infection with Vibrio sp. - Proc. a. Meet. Wld Maricult. Soc. 4, 333-338.

Leibovitz, L., 1978. Shellfish diseases. - Mar, Fish. Rev. 40, 61-64.

Lightner, D. V., 1975. Some potentially serious disease problems in the culture of penaeid shrimp in North America. In: Proceedings of the 3rd US-Japan meeting on aquaculture. Fish. Ag. Jap. Govt, Jap. Sea reg. Fish. Res. Lab., 75-97.

Lightner, D. V. \& Lewis, D. H., 1975. A septicemic bacterial disease syndrome of penaeid shrimp. Mar. Fish. Rev. 37 (5-6), 25-28.

Lightner, D. V., Redman, R. M. \& Bell, T. A., 1983. Infectious hypodermal and hematopoietic necrosis, a newly recognized virus disease of penaeid shrimp. - J. Invertebr. Pathol. 42, 62-70.

Mackin, J. G., 1962. Oyster disease caused by Dermocystidium marinum and other microorganisms in Louisiana. - Publ. Inst. mar. Sci. Univ. Texas $7,132-229$.

Mackin, J. G., Owen, H. M. \& Collier, A., 1950. Preliminary note on the occurrence of a new protistan parasite, Dermocystidium marinum n. sp. in Crassostrea virginica Gmelin. - Science, N. Y. 111, 328-329.

Marteil. L., 1969. La maladie des branchies des huitres Portugaises des côtes francaises de l'Atlantique. Données générales sur la maladie des branchies. - Revue Trav. Inst. Pêch. marit. 33 (2), $145-150$.

Matsusato, T., 1975a. Bacterial tuberculoidosis of cultured yellowtail. In: Proceedings of the 3rd USJapan meeting on aquaculture. Fish. Ag. Jap. Govt, Jap. Sea reg. Fish. Res. Lab., 115-118.

Matsusato, T., 1975b. On the lymphocystis disease in cultured yellowtail. - Fish. Pathol, 10,92-93.

Moore, M. N., 1976. Cytochemical demonstration of latency of lysosomal hydrolyses in digestive cells of the common mussel, Mytilus edulis, and changes induced by thermal stress. - Cell Tiss. Res. $175,279-287$.

Moоre, M. N., 1977. Lysosomal responses to environmental chemicals in marine invertebrates. In: Pollutant effects on marine organisms. Ed. by C. S. Giam. Heath, Lexington, Mass., $143-154$.

Munro, A. L. S., 1982. The pathogenesis of bacterial diseases of fish. In: Microbial diseases of fish. Ed. by R. J. Roberts. Acad. Press, London, 131-149.

Muroga, K. \& Egusa, S., 1970. Vibrio anguillarum isolated from Ayu in freshwater farm ponds. Fish Pathol. 5, 16-20.

Muroga, K., Jo, Y. \& Nishibuchi, M., 1976. Vibrio anguillarum isolated from the European eel cultured in Japan. - J. Fac. Fish. Anim. Husb. Hiroshima Univ. 15, 29-34.

Nakajima, K. \& Egusa, S., 1968. Studies on a new trypanorhynchan larva Callotetrarhynchus sp., parasitic on cultured yellowtail. I. - Bull. Jap. Soc. scient. Fish. 34, 792-809.

Nigrelli, R. F, 1952, Virus and tumors in fishes. - Ann. N. Y. Acad. Sci. 54, 1076-1092.

Nishimura, T., Toba, M., Ban, F, Okamoto, N. \& Sano, T., 1981. Eel rhabdovirus, EVA, EVEX and their infectivity to fishes. - Fish Pathol. 15, 173-184.

Novotny, A. J., 1978. Vibriosis and furunculosis in marine cultured salmon in Puget Sound, Washington. - Mar. Fish. Rev. 40 (3), 52-55.

Nybelin, O., 1935. Untersuchungen über den bei Fischen krankheitserregenden Spaltpilz Vibrio anguillarum. - Meddn. St. Unders. o. FörsAnst. SöttvattFisk, 8, 5-62.

Oprandy, J. J., Chang, P. W., Pronovost, A. D., Cooper, K. R., Brown, R. S. \& Yates, V. J., 1981. 